$P-279$

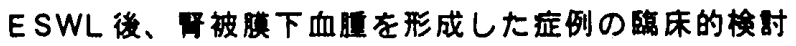

山形市立病院阁生館! 专形大学2)

紊藤雅昭! 安達裕一"1)

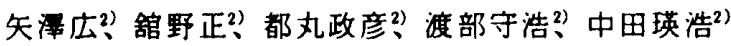

平成 4 年 4 月より平成 6 年 9 月までの 2 年 6 ケ月の間に 576 症例に対して E SWLをのへ 1,181 回施行

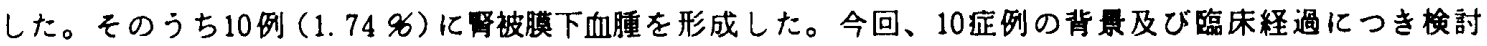
した。治㫫にはSonolith 3,000 を用いた。

【男女比】：男 2 例、女 8 例。【年龄分布】：30代1例、40代 2 例、50代 4 例、60代1例、70 代 2 例。 【結石分類】：単発 7 例、多発 3 例。 $\mathrm{R} 1 ： 6$ 例、R $2 ： 3$ 例、R $3: 1$ 例。【ショット数】：1,600 発 1 例、1,800 発 1 例、2,000 発 4 例、2,800 発 1 例、3.200 発 1 例。【電圧】 $13.0 \mathrm{Kv} 5$ 例、13.5 Kv 4 例、

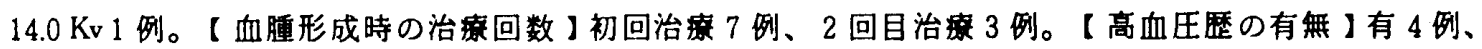
無 6 例。【血腫形成時の疼痛の有無】有 8 例、無 2 例。【血腫形成時のショックの有無】有 2 例、無 8 例。【血腫形成確認時期】治境中 2 例、䍿日 6 例、1 週後 1 例、1 ケ月後 1 例。【竞血の增悪の有無】

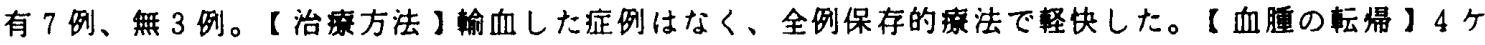
月から12ヶ月で吸収されたもの6 例、経過钼察中のもの2 例、不明 2 例。【その他】高血圧が增覀した と思われる症例 1 例。ESWL 治廉直前にTULを施行し stent 留置した症例が 2 例あった。【考察】

以上より登被膜下血腫の臨床怔状としてショックを呈するすのがある一方で、舞症状に経過するすの や分血が進まない症例があり、発見が遇れる場合があることが指畝される。術中に発見された症例すお り、エコーモニターが早期発見には有用であると考えられる。処目として的血を要したものはなく保存 的庩法で軽快した。また血腫は約1年後にはほとんどが吸収されていることが判明した。

\title{
P-280 被真下血目発生におけるESWL施行条件の模时
}

\author{
藤戸 章 ${ }^{1}$ 、米田公彦 2 、内田 睦 2 、渡造 決 $^{2}$ \\ 1古贺總合病院泌尿器科 \\ 2京都府立医科大学泌尿器科学教室
}

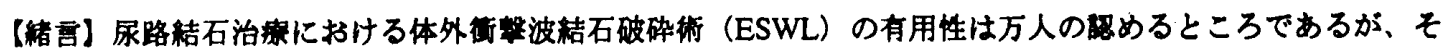

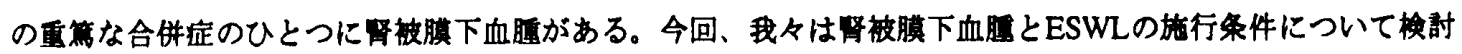
したので報告する。【対象およひ方法】対象は1988年より1993年の間に、EDAP・LT-01によりESWLを施行し

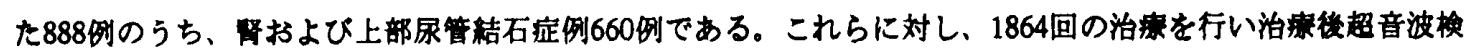

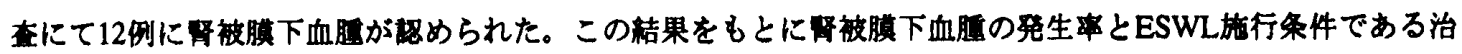

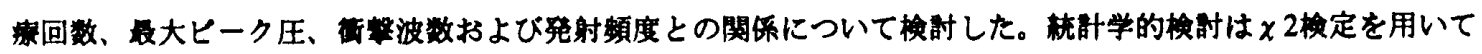
行った。【結果】1）初回の治㙩で血属が䛱められたのは660回中5例、2回目では455回中2例、3回目では292回

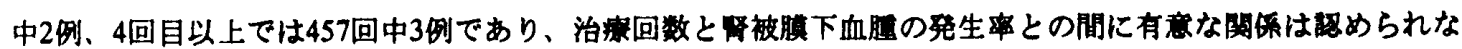
かった。2）良大ヒーー压が10〜77\%で血腫が認められたのは579回中2例、78〜90\%では284回中1例、91〜100

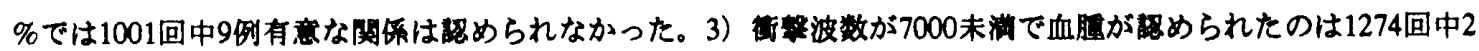
洌、7000以上14000末消では330回中4例、14000以上では260回中6例と、得波数が増加するに従い有意に血䏣

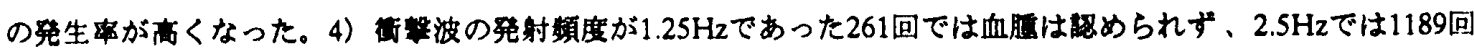
中3例、5Hz以上では414回中9例之、発射顂度が增加するに従い有意に血蜰の発生率が高くなった。【考察】

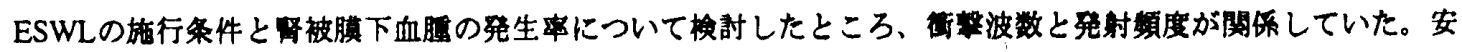

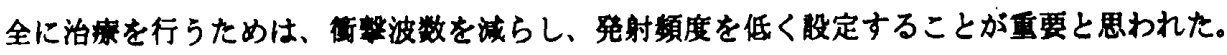

